1 Bridgwood A, Lilly R, Thomas M, Bacon J, Sykes W, Morris S. Living in Britain 1998. London: Stationery Office, 2000

2 Secretary of State for Scotland. Towards a healthier Scotland. Edinburgh: Stationery Office, 1999

3 Dorset R, Marsh A. The health trap: poverty, smoking and lone parenthood. London: Policy Studies Institute, 1998.

Graham H, Der G. Patterns and predictors of smoking cessation among British women. Health Promot Internation 1999;14:231-9.

5 Graham H, Der G. Influences on women's smoking status: the contribution of socioeconomic status in adolescence and adulthood. Eur J Public Health 1999;9:137-41.

6 Secretary of State for Health. Smoking kills. London: Stationery Office, 1999.

7 Secretary of State for Health. Saving lives: our healthier nation. London: Stationery Office, 1999 .

8 Joossens L. Smuggling and cross-border shopping of tobacco products in the European Union. London: Health Education Authority, 1999.

9 Rowell A, Bates C. Tobacco smuggling in the UK. London: Action on Smoking and Health, 2000.

10 Joossens L, Raw M. Cigarette smuggling in Europe: who really benefits? Tob Control 1998;7:66-71.
11 Jha P, Chaloupka FJ. The economics of global tobacco control. BMJ 2000;321:358-61

12 Carstairs V, Morris R. Deprivation and health in Scotland. Health Bull Edinb 1990;48:162-5.

13 Parry O, Thomson C, Fowkes FG. Life course data collection: qualitative interviewing using the life grid. Sociological Research Online 1999;4(2) on www.socresonline.org.uk/socresonline/4/2/parry.html (accessed 5 July 2001).

14 Joossens L, Raw M. How can cigarette smuggling be reduced? BMJ 2000;321:947-50.

15 Gaunt-Richardson P, Amos A, Howie G, McKie L, Moore M. Women, low income and smoking-breaking down the barriers. Edinburgh: Action on Smoking and Health Scotland/Health Education Board for Scotland, 1999.

16 Crosier A. A rapid mapping study of smoking projects and services targeted at people living on low income and/or minority ethnic groups. London: Health Development Agency, 2001.

(Accepted 29 June 2001)

\title{
Mortality in children registered in the Finnish child welfare registry: population based study
}

\author{
Mirjam Kalland, Tiina H Pensola, Jouni Meriläinen, Jari Sinkkonen
}

Studies have shown inverse associations between childhood social class and mortality, ${ }^{1}$ and others have shown higher mortality in children in care. ${ }^{23}$ However, to our knowledge, only one study has investigated mortality in children in care with results specific to sex and cause of death. ${ }^{3}$ Mortality in that study was higher than expected among boys, although mortality related to age at the time of death was not reported. ${ }^{3}$

In Finland, children are cared for within the child protection system up to the age of 18 . Our specific interest lies in whether mortality before age 18 in children in care is higher than expected on the basis of figures for the general population, reflecting failure in the child protection system, or whether mortality is increased from age 18, reflecting difficulties in adapting to independent living.

\section{Methods and results}

The basic data source was the Finnish child welfare registry. The data were completed by individual linkage with the Finnish cause of death registry, using the personal identification number of each child. The study covered all children in Finland who were taken into care between 1 January 1991 and 31 December 1997 $(\mathrm{n}=13$ 371). One per cent (133) could not be linked to the cause of death registry owing to errors in the personal identification number. All subjects were born between 1 January 1973 and 31 December 1997 and followed up until 31 December 1999 or, if earlier, their 25th birthday or, if earlier, their death. During the study period 106 individuals (32 females and 74 males) died. Mortality ratios standardised for age were used to compare the mortality of children in the cohort (girls and boys separately) with that of the general population of the same age in Finland.

In this cohort, both sexes had higher mortality than would have been expected on the basis of general population figures (table). We also compared the mortality of the cohort with that of Finnish people aged
5-24 from the manual class. ${ }^{4}$ The mortality ratio for females was 282 (95\% confidence interval 189 to 405$)$, and that for males was 218 (169 to 275), indicating that mortality was higher in comparison with this socially disadvantaged group.

The higher mortality of the cohort is related to deaths caused by substance misuse, accidents, and suicide. Six females and 29 males aged 15-24 years committed suicide, with mortality ratios of 353 (130 to 768) and 242 (162 to 348) respectively. Deaths related to alcohol and drug misuse also occurred at a higher rate than expected; the mortality ratio for females was 841 (385 to 1597), and that for males was 420 (291 to 587).

Fourteen girls and 24 boys died before the age of 18, of whom seven girls and 11 boys died of illness (four girls and seven boys aged <11). This can be attributed to an increase in acute and chronic health conditions and developmental delays among children in foster care. ${ }^{5}$

\section{Comment}

We found that both females and males in the child welfare registry cohort had excess mortality in comparison with the general population or the manual class. Excess mortality of males was not higher than that of females (see table). The belief that girls are more resilient to environmental factors than boys was thus not

Save the Children, Finland, PO Box 177 Lapinrinne 2 , FIN-00180 Helsinki, Finland Mirjam Kalland researcher Jari Sinkkonen senior research officer

Population Research Unit, Department of Sociology, PO Box 18 , FIN-00014 University of Helsinki, Finland Tiina H Pensola researcher

National Research and Development Center for Welfare and Health, Siltasaarenkatu 18 Box 220, FIN-00531 Helsinki, Finland Jouni Meriläinen planning officer

Correspondence to: M Kalland mirjam.kalland@ pela.fi

BMJ 2001;323:207-8

Mortality ratios standardised for age* of Finnish people aged 1-24 in the child protection system in 1991-9, and the number of deaths and person years

\begin{tabular}{lccccc} 
& \multicolumn{2}{c}{ Females } & & \multicolumn{2}{c}{ Males } \\
\cline { 2 - 3 } \cline { 6 - 6 } $\begin{array}{l}\text { Age group } \\
\text { (years) }\end{array}$ & $\begin{array}{c}\text { Mortality ratio } \\
(\mathbf{9 5 \%} \text { CI) }\end{array}$ & $\begin{array}{c}\text { Deaths/ } \\
\text { person years }\end{array}$ & & $\begin{array}{c}\text { Mortality ratio } \\
(\mathbf{9 5 \%} \text { Cl) }\end{array}$ & $\begin{array}{c}\text { Deaths/ } \\
\text { person years }\end{array}$ \\
\hline $1-10$ & $186(51$ to 476$)$ & $4 / 14626$ & & $270(117$ to 532$)$ & $8 / 15079$ \\
\hline $11-17$ & $351(137$ to 524$)$ & $10 / 16961$ & & $201(115$ to 326$)$ & $16 / 19292$ \\
\hline $18-24$ & $441(261$ to 693$)$ & $18 / 11875$ & & $318(236$ to 419$)$ & $50 / 13534$ \\
\hline $1-24$ & $330(226$ to 466$)$ & $32 / 43462$ & & $279(219$ to 350$)$ & $74 / 47905$ \\
\hline
\end{tabular}

${ }^{*}$ The mortality of Finnish males and females aged 1-24 in 1991-6 is used as a standard. 
supported. The child protection system does not cause the deaths-none of the children died as a result of abuse or violence by parents or foster parents. However, the system fails to protect adolescents from self endangering behaviour both within the system and during adaptation to independent living. The results indicate the need for continuing attention to be paid to the transition period from foster care to independence.

We thank the Ministry of Social Welfare and Health, the National Research and Development Centre for Welfare and Health, Statistics Finland, and the Data Protection Authority for giving permission to link the registers.

Contributors: MK designed and coordinated the study and wrote the paper, THP analysed the data and wrote the paper.JM did the data linkage and produced the data. JS interpreted the data, supervised the study, wrote the paper, and is the guarantor. Funding: Academy of Finland, Research Council for Culture and Society.

Competing interests: None declared.

1 Östberg V. Social class differences in child mortality in Sweden 1981-1986. J Epidemiol Community Health 1992;46:480-4.

2 Thompson AH, Newman SC. Mortality in a child welfare population: implications for policy. Child Welfare 1995;74:843-55.

3 Vinnerljung B. Mortalitet bland fosterbarn som placerats före tonåren [Mortality among children in foster care placed before teenage]. Socialvetenskaplig Tidskrift 1995;1:60-72.

4 Pensola T, Valkonen T. Mortality differences by parental social class from childhood to adulthood. J Epidemiol Community Health 2000;54:525-9.

5 Rosenfeld AA, Pilowsky DJ, Fine P, Thorpe M, Fein E, Simms MD, et al. Foster care: an update. J Am Acad Child Adolesc Psychiatry 1997;36:448-57. (Accepted 14 February 2001)

\section{Social environments and health: cross sectional national survey}

Andrew McCulloch

Institute for

Economic and

Social Research,

University of Essex,

Colchester

CO4 3SQ

Andrew McCulloch senior research officer

amccul@essex.ac.uk

BMJ 2001;323:208-9
Researchers are increasingly interested in studying the effects of the social environment on health. ${ }^{1}$ The concept of social capital has been put forward as one explanation for why some communities work better than others, with benefits for the whole of the local population. ${ }^{2}$ Social capital is applied to those features of a community that promote cohesion and a sense of belonging and that enable its members to cooperate. Similarly, criminologists have argued that the level of social organisation in a neighbourhood, or the degree to which residents are able to realise common goals and exercise social control, links the social composition of a neighbourhood and rates of deviant behaviour. ${ }^{3}$ We investigated how individual's reports of social capital and social disorganisation are associated with health outcomes among men and women aged 16 to 54 from a representative cross section of British households.

\section{Methods and results}

The British Household Panel Study is an annual survey of a representative cross section of British households. ${ }^{4}$ The first wave of interviews took place between

Table 1 Effect of social capital and social disorganisation on risk of poor health

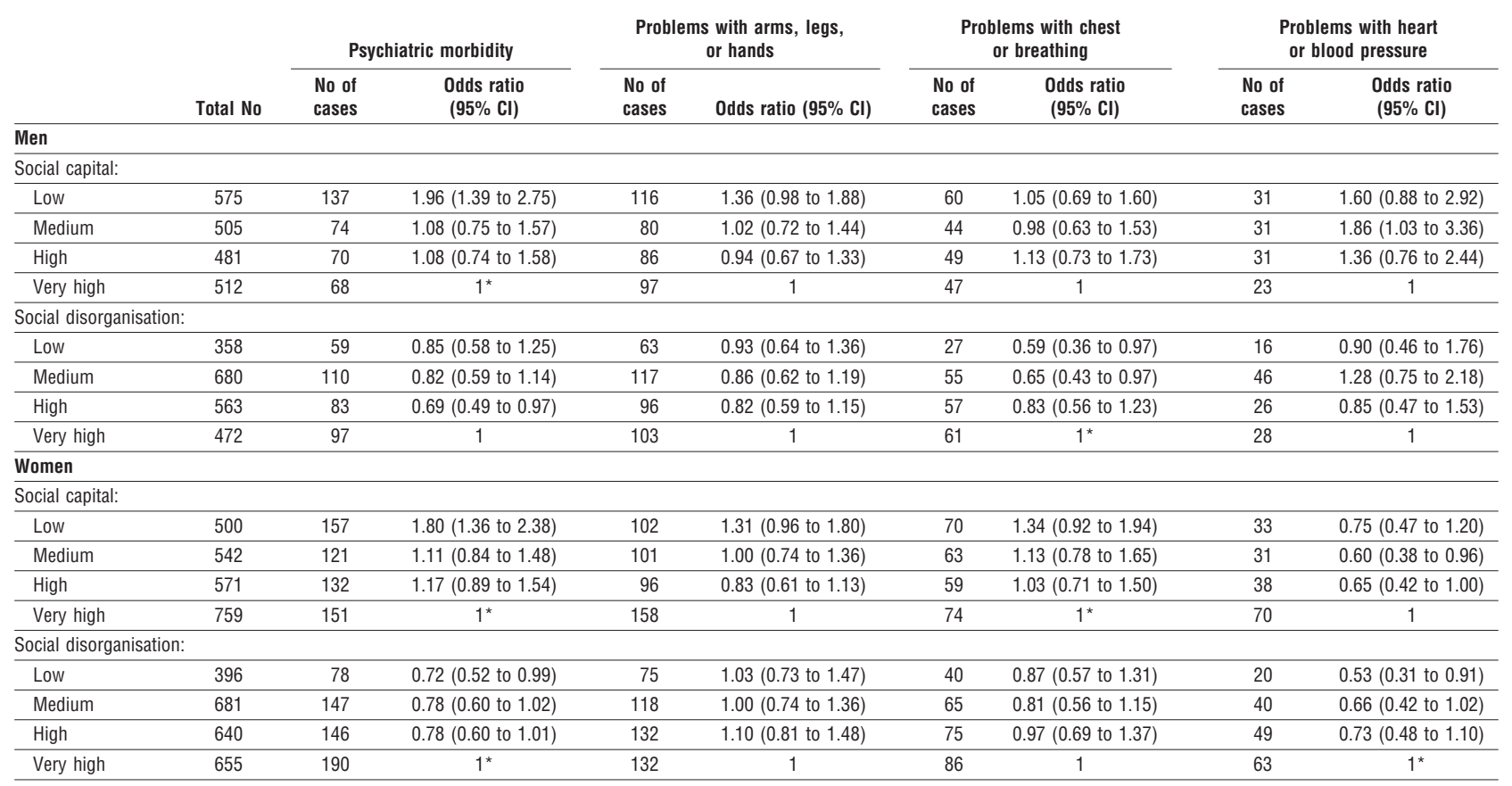

*Trend test: $\mathrm{P}<0.05$.

Models were additionally adjusted for age, education, social support, deprivation, low income, marital status, smoking, and economic activity. 